\title{
KAPITALISME DAN ISLAM (Sebuah Telaah Kritis Konsep Islam atas Konsep Kapitalis)
}

\author{
Zulaikah \\ (Jurusan Syariah STA IN Pamekasan, JI. Pahlawan Km.04 Pamekasan, email: \\ zulaikah@yahoo.co.id)
}

\begin{abstract}
A bstrak:
Kapiatalisme yang tumbuh utamanya di Amerika dan Eropa yang dikenal dengan Barat dimana sekularisme sebagai salah satu prinsip utamanya mempunyai pandangan-pandangan yang bertolak belakang dengan konsep Islâm. Hal itu bisa terekam dalam konsep yang tentang kelangkaan barang dan jasa, nilai barang yang diproduksi, dan teori harga. Benturan antara kapitalisme dengan Islâm menghasilkan sebuah dialog yang akan memperkaya perspektif di bidang ekonomi. Kelemahan yang dimiliki oleh kapitalisme menunjukkan bahwa konsep Islâm bisa menjadi alternatif dalam tataran pemikiran dan tindakan agar bisa terlepas dari jeratan ketimpangan, ketidakadilan, besarnya gap dalam bidang kehidupan ekonomi menuju sebuah sistem ekonomi yang berkeadilan, berkesimbangan dan berkesejahteraan bagi semua.

Kata Kunci:

Kapitalisme, kapitalis, dan Islâm
\end{abstract}

\begin{abstract}
A bstract:
Capitalism, that grows in America and Europe, demonstrate a contradictory view from Islamic concept. Its main principle is secularism. This could be traced from its concept on scarcity of service and commodity; produced commodity value; price theory. The dash of capitalism and Islamic concept resulting a dialogue that is able to enrich economical perspective. The weakness of capitalism shows that Islamic concept might become an alternative thought and action to release from imbalance, unjustice, and siginificant gap in economic field. It aims at the realization of fair, balance, and prosperous economic system for all.
\end{abstract}

\section{Key Words:}

Capitalism, capitalis, and Islâm 
Kapitalismedan I s âm

\section{Pendahuluan}

Banyak ekonom Muslim yang melakukan kritik terhadap sistem ekonomi kapitalisme maupun sosialisme. Pada umumnya kritikan ini berdasarkan hasil mutakhir kedua sistem tersebut dari segi ketidakadilan, penderitaan manusia dan menyekat kebebasan individu. Di samping itu asas falsafah dan teori kedua sistem tersebut juga dikaji dan disangkal. ${ }^{1}$

Sistem ekonomi kapitalisme sebenarnya bukanlah sesuatu yang sempurna dan tidak ada titik lemahnya. Titik lemah dan rentannya sistem ekonomi kapitalisme banyak disebutkan oleh para pakar mulai ekonom Muslim sampai kalangan kapitalis sendiri semisal Helmut Shcmidt, sebagaimana dikutip Chapra, bahwa ekonomi dunia telah memasuki suatu fase ketidakstabilan yang luar biasa dan perjalanan masa depannya benar-benar tidak pasti.2 Demikian juga Kissinger berkata:

"Ketidakstabilan terus berlangsung dan ketidakpastian berlanjut. Sesudah memulai masa-masa inflasi tingkat tinggi yang menyakitkan, perekonomian dunia telah mengalami suatu resesi mendalam dan laju pengangguran yang belum pernah terjadi sebelumya, dibarengi dengan laju suku bunga riil yang tinggi dan fluktuasi valuta asing yang tidak sehat. M eskipun penyembuhan kini tengah berlangsung, namun ketidakpastian tetap berlanjut. Laju suku bunga riil tetap tinggi dan ini diperkirakan akan terus meningkat, sehingga meningkatkan kecemasan adanya penyembuhan yang gagal. Krisis ini juga diperburuk oleh adanya kemiskinan di tengah orang-orang kaya di semua negara, berbagai bentuk ketidakadilan sosioekonomi, defisit neraca pembayaran yang besar, dan ketidakmampuan sebagian negara-negara berkembang untuk mencicil utang mereka. Para ekonomi tentu akan cenderung setuju dengan pandangan bahwa tidak ada teori (ekonomi) terdahulu yang tampaknya mampu menjelaskan krisis ekonomi dunia saat ini." 3

\footnotetext{
1 Muhammad Nejatullah Siddiqi, M uslim E conomic Thinking, A Survey of Contemporary Liter atu re, (Jeddah: International centrefor Research in Islamic Economics King A bdul Aziz University; leicester UK: The Islamic Fondation, 1981), hlm. 45.

2Umer Chapra, Sistem M on eter Islam (Jakarta: Gema Insani Press dan Tazkia Cendekia, 2000), hlm. xix.

3lbid.
} 
Bagi kaum sekuler dan liberal di Barat, peradaban kapitalisme termasuk sistem ekonominya dianggap sistem yang paling hebat. Francis Fukuyama pemikir amerika asal Jepang bahkan mengkalim dengan hancurnya Komunisme awal 1990-an. Bahwa peradaban Kapitalisme telah menjadi babak akhir sejarah (the end of history). ${ }^{4}$ Namun semua itu hanya ilusi belaka. Kini Kapitalisme telah diambang kematiannya. Tanda-tanda kehancuran sitem ekonomi Kapitalisme sudah terlihat beberapa tahun terakhir. Krisis keuangan yang dialami oleh AS dan negara-negara Eropa sejak pertengahan 2007 lalu seakan mempertegas suara lonceng kematian Kapitalisme. Lehman Brother, salah satu perusahaan investasi bank AS terbesar berusia 164 tahun (berdiri 1844) menyatakan pailit. Dalam sejarah AS, inilah perusahaan terbesar yang pernah bangkrut. Bank sentral AS The Fed mengambil alih Bear Stearn bank investasi di Wall Street yang sudah oleng lalu dikawinkan dengan JP Morgan Chase. Hal yang sama dilakukan terhadap American International Group (AIG), perusahaan asuransi terbesar di dunia berpusat di New Year. AIG memiliki aset 1 triliyun USD dan memiliki 100.000 karyawan terbesar di seluruh dunia. Pasar saham terguncang. Krisis ekonomi global pun diambang pintu. 5

Krisis keuangan yang menimpa negara AS mengguncang perekonomian global. Perusahaan-perusahaan besar banyak yang ambruk, bank-bank internasional dan pemerintahan diberbagai negara mengucurkan dana dalam jumlah besar ke pasar uang untuk meredakan guncangan krisis. A pa yang menimpa AS dan imbasnya yang ikut dirasakan seluruh dunia, menunjukkan rapuhnya sistem ekonomi kapitalis yang dianut negara adidaya itu dan mayoritas negara di dunia.

Krisis keuangan yang dialami AS ahir-ahir ini, merupakan krisis terburuk dalam kurun waktu berpuluh-puluh tahun sejarah perekonomian kapitalis yang dianut Negeri Paman Sam itu. Majalah Wall Street journal menyebutkan dengan kata-kata "Sistem keungan A merika terguncang hingga ke pusarnya". Presiden Bank Dunia

\footnotetext{
4 .Jamal Harwood,ed. M embedah K risis Keuangan Global, ter.MR Adhi, (Bogor: Pustaka Thariqul Izzah,2009), hlm. 7.

5 .Ibid.,hlm. 12.
} 
Kapitalismedan I s âm

Robert Zeollick menilai krisis ekonomi yang melanda dunia ahir-ahir in adalah kegagalan sistem ekonomi Kapitalisme. ${ }^{6}$

Tuliskan ini akan menguraikan kelemahan kapitalisme dalam sisi-sisi tertentu dan akan menghadirkan konsep Islâm, sehingga nampak jelas kelemahan kapitalisme dan kelebihan konsep Islâm. Inilah ciri khas tulisan sederhana ini sehingga akan membedakan dengan tulisan-tulisan yang lain.

\section{Pembahasan}

Perkembangan sistem ekonomi kapitalis memang berbeda dengan perkembangan ajaran teologis, namun implikasi pemahaman teologis yang berkembang menjadi tradisi selalu mempengaruhi pola kehidupan sosial, termasuk tingkah laku ekonomi. Kapitalisme tidak bisa begitu saja dipisahkan dari agama. Karl Marx, yang berniat mengubah sistem kapitalis yang menindas, sampai-sampai harus menyebut agama sebagai candu, agar orang mau sadar bahwa ada politisasi agama demi kepentingan ekonomi yang hanya menguntungkan segelintir orang.7 A kibatnya, Marx oleh sebagian pengikutnya kemudian disalah-artikan sebagai seseorang yang memusuhi agama. Dunia baru menjadi lebih terbuka ketika banyak pemuka agama juga berjuang membebaskan penindasan ekonomi maupun politik seperti yang terwakili oleh gerakan teologi pembebasan (liberation theology) di A merika Latin. ${ }^{8}$

Sekarang agama tidak mempunyai ruang dalam politik, sehingga agama juga tidak mempunyai ruang dalam sistem ekonomi, termasuk sistem apapun, baik sistem bagi individu, komunitas maupun negara, maka apa yang menjadi hak kaisar serahkan kepada kaisar dan apa yang menjadi hak Allâh serahkan kepada Allâh.

6 Iffah Rohmah, Kesengsaraan Dunia: Buah Sistem Ekon omi Kapitalis-Liberalis, Makalah Muktamar Majel is Taklim, Jatim Internasional Expo Surabaya,28Desember 2008.

7 Menurut Marx, agama adalah ilusi yang nyata, bahkan lebih buruk lagi, ia merupakan sebuah ilusi yang secara jelas memiliki konsekuensi kejahatan. Agama adalah sebuah contoh ideologi yang paling ekstrem, sebuah sistem kepercayaan yang tujuannya hanya menyediakan alasan untuk menjaga kelangsungan kepentingan penindas. Lihat Daniel L. Pals, Seven Theories Of Religion (London: Oxford University, Press, 1996), hlm. 138.

8 Fachrizal A. Halim, Beragama dalam B elenggu K apitalisme, (Magelang: Indonesia Tera, 2002), hlm. xiii. 
Agama adalah milik Allâh, sedangkan tanah air ini milik semua warganya.

Kapitalisme tegak atas dasar pemisahan agama dengan kehidupan (sekularisme) ide ini menjadi aqidahnya (sebagai asas), sekaligus sebagai qiyâdah fikriyah (kepemimpinan ideologis) serta qâ'idah fikriyah (kaidah berfikir)-nya. Berdasarkan qâ'idah fikriyah ini, mereka berpendapat bahwa manusia berhak membuat peraturan hidupnya. Mereka pertahankan kebebasan manusia yang terdiri dari kebebasan, berakidah, berpendapat, hak milik, dan kebebasan pribadi. Dari kebebasan hak milik ini lahir sistem ekonomi kapitalis, yang termasuk perkara paling menonjol dalam ideologi ini atau yang dihasilkan oleh keyakinan ideologi ini. Oleh karena itu, ideologi tersebut dinamakan ideologi kapitalisme. Sebuah nama yang diambil dari aspek yang paling menonjol dalam ideologi tersebut.9

Pada dasarnya, lahirnya ideologi ini terjadi ketika para kaisar dan raja di Eropa dan Rusia telah menggunakan agama sebagai sarana untuk mengeksploitasi, medalimi dan menghisap darah rakyat. Mereka juga menggunakan para pemuka agama sebagai kuda tunggangan untuk tujuan itu, dari sanalah kemudian terjadi partarungan dahsyat yang di tengah pertarungan tersebut muncul para filsuf dan pemikir, seperti Machiofelli, Adam Smith dan Ricard yang mengingkari agama secara mutlak, serta munculnya mereka yang mengakui agama tetapi tetap menyerukan pemisahan agama tersebut dari kehidupan, sehingga mayoritas filusuf dan pemikir menetapkan satu ide, yaitu pemisahan agama dari realitas kehidupan, dari sana wajar jika kemudian lahir ide pemisahan agama dari negara. 10

Kemudian disepakati mengenai ketidakperluan membahas agama dari segi, apakah harus ditolak atau diakui. Pembahasan secara intelektual benar-benar telah dibatasi mengenai pemisahan agama Nasrani dari posisi interaksi antarsesama manusia.

Dalam hal ini, mereka membangun ide jalan tengah (kompromi) antara para gerejawan yang menghendaki segalanya

\footnotetext{
9 Taqi al-Dîn al-Nabhani, N izhâm al- Islâm, Cet. VII, (tt:: H izbut Tahrir, 2001), hlm. 26. 10 Mahmûd A bu al- Su'ûd, Khutut Raisiyyah fî al-I qtishâdi Islâmî, (Kuwait: Maktabah al Manâr al-Islâmiyah, 1968), hlm. 6-9.
} 
Kapitalismedan I s âm

tunduk kepada mereka dengan mengatasnamakan agama dan undercover agama, dengan para filsuf dan pemikir yang mengingkari eksistensi agama dan kekuasaan para pemuka agama. Ide inilah yang telah menyelesaikan pertarungan antara dua kubu; yaitu tidak mengingkari agama dan tidak memberikan ruang bagi agama dalam kehidupan, tetapi ide tersebut memisahkan agama dari segala sistem kehidupan. A kidah inilah, yaitu akidah yang memisahkan agama dari kehidupan, merupakan akidah yang dianut oleh Barat seluruhnya. A kidah ini merupakan kaidah berfikir yang membangun seluruh pemikiran dan dipropagandakan di seluruh dunia.11

Ketika akidah kapitalisme melontarkan ide pemisahan agama dari kehidupan, ia menyukai dan menetapkan ide bahwa agama merupakan interaksi dan hubungan antara individu dengan penciptanya saja, agama juga tidak mempunyai hubungan dengan sistem kehidupan. ${ }^{12}$

Karena itu kebebasan berakidah merupakan sesuatu yang diagung-agungkan, kebebasan ekonomi bahkan lebih diagungagungkan lagi, sehingga menurut aqidah kapitalisme ini interaksiinteraksi ekonomi tersebut tidak boleh dibatasi. Dari sinilah muncul ide, biarlah dia bekerja, biarlah dia melangkah sesukanya kapan saja, jauh dari ikatan apa pun yang lahir dan perspektif agama untuk mengatur tingkah laku, interaksi dan sistem.

Ketika sistem ekonomi kapitalis secara praktis diterapkan di seluruh negeri kaum Muslim, karena negeri-negeri ini jatuh dalam cengkeraman imperialisasi, maka menjadi urgen untuk mengenal dasar sistem dan pemikiran utama yang melandasinya, serta memberikan gambaran yang jelas mengenai sistem yang membangun ekonomi politik (political economy) tersebut dalam aqidah kapitalisme. Sehingga para pencinta kapitalisme di negeri-negeri Islâm dapat merasakan absurditas sistem ini, serta kontradiksinya dengan Islâm dan ketidakbolehannya untuk mempropagandakan, maupun memaksakannya sebagai kajian-kajian di berbagai universitas di negeri-negeri Islâm, selain sebagai pengetahuan dalam rangka

11 A hhmad al-Najjar, A I-M adkhal Ilâ N azhariyyah al-Iqtishâdiyyah al-I slâmiyyah, (Beirut: Dâr al-Fikr, 1974), hlm. 69-70.

12 Abdul Qadim Zallum, Serangan Amerika untuk M enghancurkan Islam, terj. M. AlKhaththath, (Bogor: Pustaka Thariqul Izzah, 1996), hlm. 16. 
mengkritiknya serta menjelaskan berbagai cacat, kemunduran, kerusakannya, dan menonjolkan keagungan pemikiran Islâm yang dibawa oleh sistem ekonomi Islâm.

Setelah membahas dan mempelajarinya, terlihat bahwa sistem ekonomi kapitalis tersebut dibangun berdasarkan tiga asas yaitu:13 Pertama, masalah kelangkaan barang dan jasa. Dasar ini menjadi fondasi dalam ekonomi politik kapitalis. Masalah kelangkaan relatif tersebut adalah masalah ketidakcukupan barang dan jasa (service) untuk memenuhi kebutuhan manusia yang terus berkembang. Inilah masalah ekonomi terbesar yang dihadapi oleh masyarakat kapitalis menurut pandangan mereka. Sementara pemikiran ekonomi politik kapitalis berpandangan, bahwa manusia mempunyai kebutuhankebutuhan yang menuntut untuk dipenuhi, sehingga harus ada alatalat pemuas kebutuhan tersebut. Kebutuhan-kebutuhan ini juga hanya bersifat material murni, karena adakalanya berupa kebutuhan yang dapat diindera dan dirasakan manusia, seperti kebutuhan manusia terhadap jasa dokter dan guru. ${ }^{14}$

Sementara kebutuhan imaterial ma'nawi (non fisik), seperti rasa bangga dan, atau kebutuhan spiritual, seperti penyucian (penghormatan setinggi-tingginya), semua itu keberadaannya secara ekonomis tidak pernah diakui oleh cara pandang pemikiran kapitalis, dan semuanya tadi tidak mempunyai tempat di mata orang-orang kapitalis, serta tidak mempunyai ruang ketika melakukan pembahasan ekonomi.

Mengenai barang dan jasa yang dianggap sebagai pemuas kebutuhan dalam ekonomi politik kapitalis maka barang menurut konsepsi mereka adalah alat pemuas kebutuhan yang dapat diindra dan dirasakan. Sedangkan jasa adalah alat pemuas kebutuhan yang dapat dirasakan tetapi tidak dapat diindra. Sementara aspek yang akan dipuaskan (dipenuhi) dengan barang dan jasa adalah manfaat (utility) yang ada di dalamnya. Manfaat (utility) ini bersifat spesifik; jika barang memenuhi spesifikasi ini maka ia layak untuk memenuhi

13 Muhammad Baqir al-Sadr, Iqtihsâdunâ, hlm. 217. Kesalahannya adalah ketika menganggap asas ekonomi politik (political economy) terbatas pada kebebasan pemilikan, kebebasan bertindak, dan kebebasan konsumsi.

14 Suherman Rosyidi, Pengantar Teori Ekonomi Pendekatan Kepada Teori Ekonomi M ikro dan M akro, (Jakarta: Raja Grafindo Persada, 2004), hlm. 77-78. 
kebutuhan, di samping bahwa kebutuhan secara ekonomi bermakna keinginan (want) sehingga sesuatu yang bermanfaat (utility) secara ekonomi adalah apa saja yang diinginkan, baik yang mendesak (primer) maupun tidak.15

Tanpa memandang anggapan orang terhadapnya, bahwa ia bermanfaat sementara yang lain menganggapnya berbahaya, maka yang mempunyai utility secara ekonomi adalah selama masih ada orang yang menginginkannya, meskipun opini publik menganggapnya tidak mempunyai manfaat (utility). Minuman keras dan ganja, dalam kaca mata para ekonom adalah sesuatu yang mempunyai utility, ketika masih ada orang yang menginginkannya, hal ini banyak terdapat di dunia kapitalis. Menurut pandangan ini, kaum kapitalis hanya akan memandang alat pemuas kebutuhan, sebagai alat yang bisa memuaskan kebutuhan, tanpa memperhatikan pertimbangan lain. Maka, pandangan terhadap barang dan jasa dipandang sebagaimana apa adanya, bukan sebagaimana mestinya. Karena itu, minuman keras mempunyai nilai ekonomi (economic value), di mana produsen minuman keras itu telah memberikan jasa manusia, demikian juga pabrik minuman keras adalah lembaga yang mempunyai investasi dalam mensejahterakan masyarakat dan mendukung sirkulasi ekonomi.

Jika minuman keras dinyatakan sebagai barang yang dapat memenuhi kebutuhan sebagian anggota masyarakat, maka jasa balet, dan aktris teater dan klub-klub judi juga dinyatakan demikian. Semua barang itu dianggap mempunyai nilai ekonomi, karena bisa memenuhi keinginan (want) yang dibutuhkan oleh anggota masyarakat, sehingga semuanya merupakan jasa ekonomi (economic service), dengan mengesampingkan anggapan yang lain.

Inilah karakter kebutuhan dalam pandangan mereka, dan inilah karakter alat-alat pemuas kebutuhan. Ekonomi kapitalis tidak pernah memperhatikan apa yang seharusnya menjadi pijakan masyarakat, selain hanya memperhatikan barang ekonomi (economic goods) dilihat bahwa semua tadi bisa memenuhi kebutuhan. Karena

${ }^{15}$ AI-N abhani, N izhâm Iqtihâodi, hlm. 21. 
itu tugas ekonomi adalah menyediakan barang dan jasa yang dapat memenuhi kebutuhan setiap orang. 16

Ketika barang dan jasa yang merupakan alat pemuas kebutuhan yang kuantitasnya terbatas dalam pandangan ahli ekonomi politik kapitalis, berarti semuanya tadi tidak cukup untuk memenuhi kebutuhan manusia yang senantiasa tidak terbatas dan beragam. Ini masalah ekonomi mendasar yang tercermin pada kelangkaan barang dan jasa secara relatif. Konsekuensi logis dari kelangkaan relatif ini adalah adanya sebagian kebutuhan yang terpenuhi secara parsial, dan ada kalanya tidak terpenuhi sama sekali. Karena itu harus ada kaidah-kaidah yang digunakan oleh anggota masyarakat untuk menentukan mana kebutuhan yang akan beruntung sehingga dapat dipenuhi, dan mana yang baginya kurang.

Masalah ekonomi itu sebenarnya adalah kebutuhan dan bahan dasar, bukan manusianya. Artinya terpenuhinya bahan dasar untuk memenuhi kebutuhan, dan bukannya terpenuhinya kebutuhan setiap anggota masyarakat sebagai manusia yang hidup di dunia. Selama masalahnya seperti ini, maka harus ada kaidah-kaidah yang dipergunakan yang sekaligus menjadi kaidah untuk mencapai tingkat produksi setinggi-tingginya sehingga pemenuhan bahan dasar tersebut bisa dilakukan. Sehingga masalah distribusi barang dan jasa berkaitan erat dengan masalah produksinya.

Adapun tujuan utama dari kajian ekonomi usaha untuk meningkatkan barang dan jasa yang dikonsumsi oleh semua orang. Karena itu, kajian mengenai faktor-faktor yang bisa mempengaruhi volume produksi nasional (GNP) menduduki posisi teratas di antara seluruh topik-topik pembahasan ekonomi. Karena pembahasan mengenai peningkatan GNP merupakan pembahasan terpenting untuk menyelesaikan masalah ekonomi, yaitu kelengkapan relatif barang dan jasa terhadap kebutuhan.

Oleh karena itu mereka meyakini, bahwa tidak mungkin menyelesaikan masalah kemiskinan dan kekurangan, selain dengan cara meningkatkan cara meningkatkan produksi (GNP). Jadi, penyelesaian masalah ekonomi yang dihadapi masyarakat hanyalah

16 Abd al-Rahmân al-Mâlikî, A I-Siyâsat al-Iqtishâdiyah al-M usthla (Al-Quds Hizb alTahrir, 1963), hlm. 21. 
Kapitalismedan I s âm

dengan pertambahan produksi, pertambahan produksi dan pertambahan produksi. ${ }^{17}$

Sesungguhnya apa yang dianut oleh sistem kapitalis, bahwa mencampuradukkan antara kebutuhan dengan alat pemuas kebutuhan dalam satu pembahasan, atau antara menghasilkan barang-barang produksi dengan cara mendistribusikannya dan menjadikan keduanya sebagai satu kesatuan adalah yang keliru. Inilah yang melahirkan kontaminasi dan intervensi dalam pembahasan-pembahasan ekonomi di kalangan orang kapitalis. Karena itu, asas pembentukan ekonomi dalam ideologi kapitalis adalah asas yang salah. Kebutuhan-kebutuhan yang menuntut untuk dipenuhi dan dianggap terbatas pada materi adalah juga salah dan bertentangan dengan realitas (fakta) kebutuhan-kebutuhan tersebut. Sebab ternyata ada kebutuhan moral dan kebutuhan spiritual. Di mana kebutuhan tersebut masing-masing menuntut agar dipenuhi sebagaimana kebutuhan yang bersifat materi, dan masing-masing membutuhkan barang dan jasa untuk memenuhinya.

Adapun pandangan para ekonomi kapitalis terhadap kebutuhan dan manfaat, sebagai apa adanya, bukan masalah-masalah yang semestinya harus dijadikan pijakan oleh masyarakat, adalah pandangan yang mencerminkan bahwa para pakar ekonomi kapitalis itu tidak melihat manusia yang bersifat materi semata, 18 tanpa kecenderungan-kecenderungan spiritual, pemikiran-pemikiran tentang budi pekerti, dan tujuan-tujuan yang bersifat non materi, mereka tidak pernah memperhatikan masalah-masalah yang semestinya harus dijadikan pijakan oleh masyarakat, seperti ketinggian moral dengan menjadikan sifat-sifat terpuji sebagai dasar bagi interaksinya.

Salah satu contohnya adalah ketinggian spiritual, dengan menjadikan kesdaran hubungan dengan Allâh sebagai sesuatu yang

17 Gregory Grossman, Sistem Ekonomi Islam, (Jakarta: Bumi Aksara, 1995), hlm. 6-7. 18 Manusia adalah materi. Allâh swt. telah meniupkan ruh sebagai rahasia kehidupan (nyawa) pada manusia. Allâh juga telah memberikan potensi hidup yang tercermin dalam tiga potensi hidup yang tercermin dalam tiga potensi (khosiyah), yakni: kebutuhan jasmani, naluri-naluri dan akal (idrak). Semuanya telah ada pada setiap manusia yang hidup. Lihat Muhammad Husayn A bd Allâh, M afâhim Islâmiyyah, Juz 1, (Beirut: Dar al-Bayâriq, 1994), hlm. 49. 
mengendalikan interaksi-interaksi tersebut dalam rangka memperoleh ridla Allâh.

Perhatian para ekonom kapitalis terpusat pada manfaat, sebagai sesuatu yang bisa memenuhi kebutuhan material semata. Maka, manusia yang memiliki pandangan seperti ini pada manusia yang lain serta membangun kehidupan ekonomi dengan berpijak pada pandangan semacam ini, adalah orang yang paling berbahaya bagi masyarakat dan seluruh manusia. Sedangkan dari sisi lain, seluruh harta dan jerih payah yang mereka sebut dengan barang dan jasa itu diperoleh seseorang hanya semata-mata untuk dimanfaatkan serta menjadi alat tukar-menukar yang bisa membentuk hubungan antara satu orang dengan orang lain, maka ketika itu harus dilihat sebagai masalah-masalah yang semestinya harus dijadikan pijakan oleh masyarakat tatkala mereka menginginkan harta dan kebutuhan, baik secara global maupun rinci. Karena itu, perhatian terhadap barang-barang produksi, dilihat dari segi barang-barang tersebut memuaskan kebutuhan, tanpa memperhatikan masalah-masalah yang semestinya harus dijadikan pijaka oleh masyarakat. Hal itu sama halnya dengan memisahkan barang ekonomi dengan interaksiinteraksi tersebut, dan ini tentu tidak mungkin. Karena barang-barang produksi tersebut dipergunakan manusia untuk saling tukarmenukar, dengan begitu terbentuklah interaksi di antara mereka. Interaksi-interaksi itulah yang membentuk masyarakat. Maka, ketika melihat barang-barang produksi, ia harus dilihat sebagai masalahmasalah yang semestinya harus dijadikan pijakan oleh masyarakat. Karena itu, seseorang tidak boleh mengklaim barang tersebut bermanfaat, semata karena adanya orang yang menginginkannya. Baik barang itu esensinya membahayakan atau tidak; maupun mempengaruhi interaksi-interaksi manusia atau tidak; ataupun yang esensinya diharamkan menurut keyakinan orang atau tidak. Melainkan, barang tersebut harus dianggap bermanfaat, apabila memang esensinya bermanfaat, sebagai perkara yang semestinya dijadikan pijakan oleh masyarakat.

Berdasarkan hal ini, ganja, candu dan sebagainya tidak boleh dianggap sebagai barang yang bermanfaat, atau bahkan menganggapnya sebagai barang-barang produksi, semata karena ada orang yang menginginkannya. Ketika melihat manfaat suatu barang, 
harus melihat pengaruh barang-barang produksi tersebut terhadap hubungan masyarakat. Dengan kata lain, barang tersebut harus dilihat sebagai masalah-masalah yang semestinya dijadikan pijakan oleh masyarakat, dan tidak boleh dilihat hanya sebatas barang saja.

Konsekuensi adanya pencampuradukan pembahasan tentang pemuasan kebutuhan-kebutuhan tersebut dengan alat-alat pemuasnya, serta konsekuensi pandangan para ekonom terhadap alat-alat pemuas dengan melihatnya hanya sebatas pemuas kebutuhan semata, tidak dengan melihatnya sebagi sesuatu yang lain, menyebabkan pandangan para ekonom tersebut dibangun dengan berpijak pada produksi kekayaan lebih besar daripada untuk memenuhi kebutuhan masyarakat.19 Bahkan pandangan terhadap distribusi tersebut menjadi sebuah pandangan yang tidak utuh. Atas dasar inilah, maka sistem ekonomi kapitalis itu hanya mengarah kepada satu tujuan, yaitu meningkatkan kekayaan negara secara total. Kemudian berusaha memeproleh tingkat produksi hingga setinggitingginya, dan terealisasikannya kemakmuran anggota masyarakat setinggi mungkin sebagai akibat adanya pertambahan pendapatan nasional (national income), dan naiknya produksi suatu negara. Memperoleh kekayaan dengan cara membiarkan mereka sebebasbebasnya bekerja, untuk memperoduksi dan mengumpulkan kekayaan tersebut.20

Oleh karena itu, ekonomi - dalam pandangan orang kapitalis bukan dibentuk dalam rangka memenuhi kebutuhan-kebutuhan individu serta terpenuhinya kebutuhan masing-masing individu secara menyeluruh, melainkan terfokus pada barang-barang yang akan memenui kebutuhan mereka. Dengan kata lain, terpenuhinya kebutuhan-kebutuhan secara kolektif, dengan naiknya produksi dan bertambahnya pendapatan nasional di suatu negara. Dengan cara tersebut, maka distribusi pendapatan dilakukan dengan cara kebebasan kepemilikan dan kebebasan bekerja bagi anggota masyarakat., Anggota masyarakat dibiarkan sebebas-bebasnya untuk memperoleh kekayaan apa saja yang mampu mereka peroleh, sesuai dengan faktor-faktor produksinya masing-masing, baik pemenuhan

19 C. Wrigh Mills, Kaum M arxis: Ideide D asar dan Sejarah Perkembangannya, terj. Imam Muttaqien, (Yogyakarta: Pustaka Pelajar, 2003), hlm. 77-78.

20 al-Mâlikî, al-Siyâsat, hlm. 13. 
tersebut dapat dipenuhi untuk seluruh anggota masyarakat, atau terjadi pada sebagian orang, sedangkan yang lain tidak. Inilah politik ekonomi (political ekonomi), atau ekonomi kapitalis. Ini jelas-jelas keliru dan bertentangan dengan realitas, serta tidak menyebabkan naiknya taraf kehidupan individu secara menyeluruh. Begitu pula, tidak pernah menghasilkan kemakmuran bagi setiap individu rakyat.

Kesalahan terletak pada kenyataan bahwa kebutuhankebutuhan yang menuntut pemenuhan tersebut adalah kebutuhankebutuhan individu sebagai kebutuhan manusia (misalnya kebutuhan si Muhammad, si Soleh, si Hasan dan lain-lain), bukan kebutuhankebutuhan segenap manusia, umat, ataupun bangsa. Sedangkan yang berupaya memenuhi kebutuhan-kebutuhannya adalah individu. Baik pemenuhannya untuk dirinya secara langsung, seperti makan atau pemenuhannya terhadap ummat.

Masalah ekonomi sebenarnya hanya bertumpu pada distribusi alat-alat pemuas tersebut kepada individu, yaitu pendistribusian barang dan jasa kepada individu ummat atau bangsa. Bukan bertumpu pada kebutuhan-kebutuhan yang dituntut oleh ummat atau bangsa secara total, tanpa melihat masing-masing individunya. Dengan kata lain, permasalahannya adalah kemiskinan yang menimpa individu. Bukan kemiskinan yang menimpa negara. Sehingga membahas sistem ekonomi adalah membahas tentang bagaimana kebutuhan-kebutuhan pokok tiap individu itu bisa terpenuhi. Bukan membahas tentang bagaimana agar barang-barang produksi tersebut bisa diproduksi.

Oleh karena itu faktor-faktor yang mempengaruhi laju produksi dalam negeri (national production) itu tidak lagi menjadi pembahasan yang berhubungan dengan pemenuhan seluruh kebutuhan pokok individu masing-masing, secara menyeluruh. Akan tetapi, tema pembahasannya malah mengarah kepada pembahasan tentang kebutuhan-kebutuhan pokok manusia, sebagai manusia, serta pembahasan tentang distribusi kekayaan bagi anggota masyarakat, untuk menjamin terpenuhinya seluruh kebutuhan primer mereka, di mana hal itu menjadi suatu keharusan dan menduduki posisi utama.Sedangkan mengenai kelangkaan barang dan jasa yang bersifat relatif yang dianggap sebagai masalah ekonomi yang senantiasa dihadapi oleh masyarakat, termasuk anggapan tentang banyaknya 
kebutuhan sedangkan alat pemuasnya terbatas, dengan kata lain ketidakmampuan barang dan jasa untuk memenuhi semua kebutuhan manusia secara menyeluruh, bahkan hal ini dijadikan sebagai masalah utama ekonomi, adalah salah dan bertentangan dengan kenyataan. Sebab kebutuhan-kebutuhan primer (basic needs) individu, dalam kapasitasnya sebagai manusia, bukan kebutuhan sekunder ataupun tersier (lux). Meskipun, kebutuhan tersier (lux) tersebut juga bisa saja diupayakan dan dipenuhi.

Oleh karena itu, sebenarnya kebutuhan-kebutuhan primer (basic needs) tersebut terbatas kuantitasnya, di mana kekayaan dan jerih payah (tenaga) yang mereka sebut dengan harta dan jasa yang ada di dunia itu sebenarnya cukup untuk memenuhi kebutuhankebutuhan primer. Seluruh kebutuhan primer tersebut bisa saja dipenuhi secara menyeluruh oleh masing-masing konsumen. Sehingga tidak akan ada masalah dalam pemenuhan kebutuhankebutuhan primer (basic needs) tersebut, lebih-lebih dengan menganggapnya sebagai masalah ekonomi yang senantiasa akan dihadapi oleh masyarakat.

Masalah ekonomi itu sebenarnya hanya terletak pada distribusi harta dan jasa tersebut kepada tiap-tiap individu, dalam rangka memenuhi kebutuhan-kebutuhan primer (basic needs) mereka secara menyeluruh, serta membantu mereka berusaha untuk memenuhi kebutuhan-kebutuhan sekunder hingga kebutuhankebutuhan lux mereka. Sedangkan masalah yang berhubungan dengan bertambahnya kebutuhan-kebutuhan yang silih berganti itu, sebenarnya tidak ada hubungannya dengan bertambahnya kebutuhan-kebutuhan primer (basic needs) tersebut. Karena kebutuhan-kebutuhan primer manusia, dari segi manusianya (yaitu bisa memenuhi sandang, papan dan pangan, pent.) itu tidak akan pernah bertambah (bersifat statis). A kan tetapi yang bertambah dan terus meningkat adalah kebutuhan sekunder atau tersier. Bertambahnya kebutuhan-kebutuhan yang ada terkait dengan kemajuan peradaban manusia, sebenarnya hanya terkait dengan kebutuhan-kebutuhan sekunder atau tersier (lux), dan bukan kebutuhan primernya. Di mana kebutuhan-kebutuhan sekunder atau tersier tersebut memang bisa diusahakan untuk dipenuhi, sekalipun kalau tidak dipenuhi juga tidak akan menimbulkan masalah. Justru 
yang menimbulkan masalah adalah apabila kebutuhan-kebutuhan primer (basic needs) tersebut tidak terpenuhi. ${ }^{21}$

Masalah ini tentu berbeda dengan masalah pemenuhan kebutuhan-kebutuhan primer (basic needs) tiap anggota masyarakat secara menyeluruh. Karena masalah distribusi kekayaan kepada individu masing-masing untuk memenuhi seluruh kebutuhan primer mereka secara menyeluruh dan memuaskan, serta membantu tiap individu untuk memenuhi kebutuhan-kebutuhan sekunder atau tersiernya, hal ini adalah masalah yang berkaitan dengan pandangan hidup tertentu, dan bersifat khas bagi bangsa-bangsa tertentu, atau ideologi tertentu.

Hal itu berbeda dengan masalah peningkatan pendapatan nasional dengan bertambahnya produksi nasionalnya. Karena masalah tersebut menyangkut realitas negara, dilihat dari segi pertambahan kuantitas kekayaan tersebut, baik dengan cara eksploitasi, atau imigrasi, atau perluasan usaha, ataupun kerjasama. Di mana, masalah tersebut diseuaikan dengan realitas yang ada dan bisa dilaksanakan oleh setiap manusia yang bersifat universal, dan tidak menyangkut pandangan hidup tertentu, serta tidak ditunjukkan khusus bagi bangsa dan ideologi tertentu.22

Oleh karena itu, kebijakan ekonomi yang harus dibuat adalah kebijakan yang bisa menjamin distribusi kekayaan negara, baik kekayaan di dalam maupun di luar negeri, kepada seluruh anggota masyarakat, dari segi terjaminnya pemenuhan seluruh kebutuhan primer (basic needs) semua anggota masyarakat dan memuaskan mereka. Di samping terjaminnya kemungkinan tiap anggota masyarakat untuk memenuhi kebutuhan-kebutuhan sekunder atau tersier mereka. Sedangkan untuk menunaikan tingkat produksi, hal ini membutuhkan pembahasan ilmiah. Kalaupun pembahasan tersebut disinggung dalam sistem ekonomi, yaitu terpenuhinya seluruh kebutuhan individu masing-masing dengan cara menyeluruh dan memuaskan. Sebab, kadang-kadang negara tersebut kaya, dengan tingkat produksi yang tinggi, seperti Irak dan Saudi misalnya, akan tetapi kebutuhan-kebutuhan primer mayoritas anggota

21 Taqiyuddin an N abhani, N izamul Iqtisadi, hlm. 33. 22 Ibid. 
masyarakat di sana tidak semuanya terpenuhi secara menyeluruh dan memuaskan.

Dengan demikian, bertambahnya tingkat produksi tersebut tidak akan menyelesaikan masalah utama, yang harus segera dipecahkan sebelum yang lainnya, yaitu terpenuhinya seluruh kebutuhan primer semua anggota masyarakat, dengan cara menyeluruh dan memuaskan, kemudian membantu mereka untuk memenuhi kebutuhan-kebutuhan sekunder atau tersier mereka. Oleh karena itu, kemiskinan absolut (absolute poverty) dan kemiskinan struktural (structural poverty), yang menuntut harus dipecahkan adalah kemiskinan yang disebabkan tidak terpenuhinya kebutuhankebutuhan primer manusia dalam kapasitasnya sebagai manusia, bukan karena tidak terpenuhinya kebutuhan-kebutuhan yang terus meningkat, seiring dengan berkembangnya taraf kehidupan.

A dapun kemiskinan absolut (absolute poverty) dan kemiskinan struktural (structural poverty), yang menuntut harus dipecahkan itu adalah kemiskinan masing-masing anggota masyarakat, bukan kemiskinan suatu negara. Kemiskinan dan kemelaratan tiap anggota masyarakat dengan konsepsi semacam ini, tidak akan terpecahkan dengan menambah jumlah produksinya. Melainkan bisa dipecahkan dengan cara mendistribusikan kekayaan kepada seluruh kebutuhan primer setiap individu secara menyeluruh dan memuaskan, kemudian dibantu untuk memenuhi kebutuhan-kebutuhan sekundernya. 23

Kedua, nilai (value) barang yang diproduksi. Nilai barang yang diproduksi dalam pandangan kaum kapitalis adalah tingkat urgensinya, adakalanya menurut orang tertentu dan adakalanya dengan barang lain. Pada kondisi pertama disebut nilai guna (utility value), dan pada kondisi kedua disebut nilai tukar (exchange value). ${ }^{24}$

Nilai guna barang (utility value) dapat disimpulkan, bahwa nilai guna (utility value) adalah satuan dari sesuatu yang diukur berdasarkan manfaatnya yang paling akhir, yaitu manfaat satuan

23 lbid., hlm. 35

24 Karl Marx, N aqd al-Iqtishâdi Siyâsî, terj. Rasyid al-Banawî, (Beirut: Dâr al-Nahdlah al-'A rabiyyah, 1969), hlm. 13. 
tersebut ketika memuaskan kebutuhan yang paling rendah. ${ }^{25}$ Inilah yang oleh kaum kapitalis disebut dengan theory of marginal satisfaction (teori kepuasan batas). Artinya manfaat tersebut tidak diukur berdasarkan pandangan produsen, sehingga akan diukur menurut beban produksinya, karena ketika itu nilai tersebut hanya memperhatikan pandangan supply (penawaran) dengan mengesampingkan demand (permintaan), juga tidak diukur berdasarkan pandangan konsumen, sehingga akan diukur berdasarkan pandangan kadar kegunaan (utility) dan rasa butuh pada utility dengan memperhatikan faktor kelangkaan, karena ketika itu nilai tersebut hanya memperhatikan pandangan demand, minus supply.

Pada hakekatnya nilai tersebut wajib diperhatikan berdasarkan pandangan supply and demand secara simultan, sehingga utility-nya akan diperoleh ketika batas akhir terpenuhinya kebutuhan pada batas akhir pemenuhannya, yaitu ketika nilai sepotong roti ditentukan pada titik nadir rasa lapar, bukan pada saat permulaannya, juga pada saat tersedianya roti secara umum di pasar, bukan pada saat langka. Inilah nilai guna (utility value) itu. Sedangkan nilai tukar (exchange value) merupakan spesifikasi, yang ketika spesifikasi tersebut ada pada sesuatu, maka sesuatu tersebut layak untuk dipertukarkan.

Kaum kapitalis mendefinisikannya dengan daya tukar barang terhadap yang lain. Nilai tukar (exchange value) gandum terhadap jagung diukur berdasarkan kuantitas jagung yang harus diberikan untuk mendapatkan satuan gandum. Nilai guna (utility value) tersebut disebut guna (utility) saja, sedangkan nilai tukar (exchange value) disebut nilai (value) saja. ${ }^{26}$

Kaum kapitalis juga berpendapat, bahwa pertukaran tersebut hanya sempurna jika ada alat pengganti barang atau jasa yang setara atau hampir setara nilainya dengannya. Dari sinilah, maka menurut kaum kapitalis nilai (value) harus dibahas, karena nilai tersebut merupakan asas pertukaran, dan karena ia juga merupakan sifat yang dapat dinilai, juga karena ia merupakan standar yang menjadi standar

${ }^{25}$ Anthony Brewer, Kajian Kritis Das Kapital Karl M arx, terj. Joebaar Ajoeb, Jakarta: Teplok Press, 2000), hlm. 36.

26 'A qil Ahmad Hasysy, Târikh al-Fikr al-Iqtishâdî, (Libanon: Dâr al-Nahdlah al'A rabiyah, 1974), hlm. 11. 
barang dan jasa, yang dengan nilai itu juga aktivitas produktif dan non-produktif dapat diklasifikasikan sebab, produksi adalah menciptakan atau menambah kegunaan (utility).27

Produksi tidak akan sempurna kecuali dengan adanya usaha, sementara aktivitas produktif dan non produktif, serta mana yang tingkat produksivitasnya lebih tinggi dibanding yang lain bisa diklasifikasikan, semuanya memerlukan standar yang detail untuk mengukur berbagai produk dan jasa yang beragam. Standar yang detail ini adalah nilai sosial bagi produk dan jasa, atau dengan kata lain itulah penilaian komunal terhadap usaha (aktivitas) yang dicurahkan atau jasa yang diberikan.28 Penilaian ini merupakan sesuatu yang urgen, karena produksi dengan pijakan jaminan pertukaran pada masyarakat modern telah menempati posisi produksi dengan pijakan jaminan konsumsi.

Sistem ekonomi kapitalis menganggap nilai (value) bersifat bukan hakiki (esensial). Artinya, nilai (tersebut merupakan nilai) asumtif. Oleh karena itu, nilai satu kilogram daging adalah manfaat terakhir daging ketika daging tersebut di pasar benar-benar mencukupi. Nilainya yang sebanding dengan satu kilogram daging juga sama dengan komoditi lain, seperti kain, susu, gula, serta jasa seperti gaji untuk dokter, guru privat, dan upah penjahit, pembantu dan pekerja.

Mereka menyatakan, bahwa nilai (value) sesuatu akan berubah menjadi harga (price), jika satu kilo daging itu sama dengan sejumlah uang. Menurut kaum kapitalis nilai yang pertama disebut manfaat (utility) dan nilai yang kedua adalah nilai tukar (exchange value).

Makna nilai seperti ini, dengan batasan seperti ini, adalah salah, dan tidak layak disebut teori nilai (theory of value) dengan asas ini yang merupakan salah satu asas sistem ekonomi. Alasannya karena nilai komoditi apapun tiada lain adalah kadar manfaat yang terkandung di dalamnya dengan tetap memperhatikan faktor kelangkaannya.

27 Untuk lebih lengkap tentang Teori Nilai Kerja lihat Jon Ester, Karl M arx, M arxisme: A n alisis K ritis, terj. Sudarmaji, (Jakarta: Prestasi Pustaka Karua, 2000), hlm. 86.

28 Mahmud al Khalidi, Kerusakan dan Bahaya Sistem Ekonomi Kapitalis, (Jakarta: Wahyu Pres,2002), hlm. 35. 
Jadi, nilai merupakan nama untuk sebutan tertentu yang mempunyai hakikat yang nyata, dan bukannya nama sesuatu yang bersifat relatif dan asumtif. Karena itu, pandangan para ekonom kapitalis kepada nilai tersebut adalah pandangan yang salah sejak dari asasnya.

Sementara apa yang mereka sebut dengan nilai batas (marginal value) adalah perkirakan terhadap memusatnya produksi pada kemungkinan yang paling buruk berkaitan dengan definisi barang, sehingga nilai barang tersebut diperkiarakan berdasarkan batas paling rendah supaya produksinya tetap berlangsung dengan asas yang terjamin. Nilai batas tersebut juga bukan merupakan nilai barang yang sebenarnya, bahkan juga bukan merupakan harga barang.

Alasan mereka adalah karena nilai barang hanya ditentukan berdasarkan kadar manfaatnya ketika barang tersebut dinilai, dengan memperhatikan faktor kelangkaan pada waktu tersebut. Turunnya harga setelah itu juga tidak akan mengurangi nilainya, sebagaimana kenaikan harganya setelah itu juga tidak akan menambah nilainya. Karena nilai tersebut diasumsikan ketika berlangsung penilaian.

Oleh karena itu, teori batas (marginal value) sebenarnya merupakan teori harga, bukan teori nilai. Ada perdebatan antara nilai (value) dengan harga (price) menurut kaum kapitalis. Harga perkiraannya ditentukan berdasarkan banyaknya permintaan (demand) dan sedikitnya penawaran (supply), atau banyaknya penawaran dan sedikitnya permintaan secara serentak. Ini berkaitan dengan bertambahnya produksi bukan distribusi.

Sementara nilai perkiraannya ditentukan berdasarkan manfaat yang ada pada barang ketika berlangsung penilaian, dengan memperhatikan faktor kelangkaan tanpa menganggapnya sebagai bagian dari perkiraan, juga tidak dipengaruhi oleh penawaran dan permintaan secara total.

Para ekonom kapitalis mengatakan bahwa sesungguhnya manfaat-manfaat tersebut merupakan hasil usaha yang dicurahkan oleh manusia.29

29 Ibid., hlm. 95 
Jika upahnya tidak sesuai dengan usahanya, maka tingkat produksinya akan menurun. Dengan demikian, mereka ingin menyatakan bahwa metode terbaik untuk mendistribusikan kekayaan kepada anggota masyarakat adalah metode yang dapat menjamin tercapainya tingkat produksi setinggi-tingginya.

Pendapat ini jelas-jelas salah. Kenyataan yang terindra membuktikan, bahwa harta kekayaan yang diciptakan Allâh di alam ini merupakan asas manfaat bagi barang, sementara biaya (cost) yang dikeluarkan untuk menambah manfaat harta ini atau menciptakan manfaat ditambah tenaga, itulah yang menjadikannya dalam bentuk terakhirnya mampu memberikan manfaat tertentu. Maka menjadikan manfaat sebagai hasil tenaga saja adalah salah yang kontradiksi dengan fakta, dan bisa menyia-nyiakan bahan mentah serta biaya yang telah dikeluarkan, di mana biaya-biaya tersebut bisa jadi merupakan pengganti bahan baku, dan bukannya pengganti tenaga.

Kadang-kadang manfaat tersebut merupakan hasil tenaga manusia, kadang-kadang merupakan hasil dari adanya bahan mentah, kadang-kadang merupakan hasil dari keduanya sekaligus, dan bukannya hasil tenaga manusia saja. Sementara turunnya tingkat produksi, sebenarnya bukan merupakan akibat dari ketidakseimbangan antara upah dengan usaha (tenaga yang dicurahkan), tetapi kadang-kadang dihasilkan dari pengkonsumsian kekayaan di dalam negeri, dan kadang-kadang dihasilkan dari peperangan, juga kadang-kadang dari yang lain. Sehingga ketidakseimbangan antara upah dengan usaha (tenaga yang dicurahkan) bukan merupakan satu-satunya sebab turunnya tingkat produksi (GNP), sehingga membawa konsekuensi bahwa metode terbaik dalam distribusi itulah metode yang akan bisa menjamin tingginya tingkat produksi (GNP). Padahal, untuk mencapai tingkat produksi yang paling tinggi tidak ada hubungannya dengan distribusi kekayaan kepada individu, karena tingginya tingkat produksi dibahas dalam ilmu ekonomi (economic science) sedangkan distribusi kekayaan kepada rakyat dibahas oleh sistem ekonomi (economic system). 30

30 al-Nabhani, al-N izhâm, hlm. 21. 
Ketiga, teori harga. Struktur harga (structure of price) dan peran yang dimainkannya dalam produksi, konsumsi dan distribusi adalah batu fondasi sistem ekonomi kapitalis. ${ }^{31}$ Karena nilai tukar (exchenge value) di zaman modern ini telah dispesifikasikan dengan satuan penghitung (unit of account) nilainya sehingga menjadi dominan dibanding dengannya, maka nilai barang tidak disandarkan kepada barang lain, misalnya nilai 10 meter kain dinyatakan sama nilainya dengan 60 ekor ayam. Seluruh barang tersebut di seluruh penjuru dunia disandarkan kepada satu barang saja yang disebut uang (money). Penyandaran pertukaran barang dengan uang tersebut dinamakan harga (price), dengan begitu harga (price) merupakan nilai tukar barang dengan uang. Karena itu, ada perbedaan antara nilai tukar (exchange value) dengan harga (price); bahwa nilai tukar adalah penyandaran pertukaran sesuatu dengan barang lain secara mutlak, baik dengan uang, barang ataupun jasa. Sedangkan harga adalah nilai tukar barang dengan uang saja.

Konsekuensinya, seluruh harga barang mungkin naik atau turun secara serentak. Sementara mustahil naik dan turunya hargaharga tersebut tanpa konsekuensi perubahan nilai tukarnya. Sehingga harga barang adalah salah satu nilai barang-barang ini, atau dengan kata lain harga adalah nilai barang terhadap uang saja.

Ketika harga hanya merupakan salah satu nilai tukar, maka wajar ia menjadi standar: apakah barang tersebut bermanfaat (mempunyai utility) atau tidak (disutility) serta menjadi standar kadar manfaat barang.Barang atau jasa dianggap produktif dan bermanfaat (utility), jika masyarakat menilai barang atau jasa tersebut dengan harga (price) tertentu. Sementara tingkat manfaat (utility) barang dan jasa ini, akan diukur dengan harga yang diterima oleh kebanyakan konsumen yang mendorongnya untuk memperolehnya (utility atas barang dan jasa tersebut); apakah barang-barang tersebut merupakan produksi pertanian ataupun industri, ataukah jasa tersebut merupakan jasa pedagang, perusahaan transportasi, dokter, atau insinyur. ${ }^{32}$

31 Mills, Kaum M arxis, hlm. 338.

32 Ibid., hlm. 38 
Dengan memperhatikan peranan yang dimainkan harga di pasar produksi, konsumsi dan distribusi, maka akan dipaparkan pandangan ekonomi politik (politcal economy) kapitalis mengenai struktur harga (structure of price) dan pengaruhnya dalam kehidupan ekonomi kapitalis sebagai berikut.

Pertama, struktur harga adalah metode ideal untuk mengatur distribusi barang dan jasa kepada anggota masyarakat. Kaum kapitalis menetapkan, bahwa kegunaan (utility) adalah hasil usaha yang dicurahkan manusia, sehingga ketika upahnya tidak sesuai dengan usahanya, pasti akan mengakibatkan turunnya tingkat produksi.Oleh karena itu, metode ideal untuk mendistribusikan barang dan jasa kepada anggota masyarakat itulah yang dapat menjamin tercapainya tingkat produksi yang paling tinggi.

Metode ini adalah harga (price), yaitu apa yang mereka sebut dengan struktur harga (price apparatus)33atau mekanisme harga. Karena mereka beranggapan, bahwa metode ini dapat menciptakan keseimbangan ekonomi (economic equal ibrium) secara otomatis.

Dasar metode tersebut didasarkan pada dibiarkannya kebebasan konsumen untuk menentukan sendiri distribusi bahanbahan dasar yang dimiliki masyarakat pada cabang-cabang aktivitas ekonomi yang beragam dengan kesediaan mereka untuk membeli sebagian barang, dan ketidaksediaan mereka membeli sebagian yang lain. Mereka bisa membelanjakan pendapatan (income) mereka yang akan mereka peroleh untuk membeli sebagian barang dan tidak pada sebagian yang lain.Jadi, para konsumenlah yang menentukan kuantitas dan jenis produksi berdasarkan pilihan dan kebebasan mereka. Dalam hal ini, hargalah yang berjalan melalui distribusi barang dan jasa ketika bisa atau tidak bisa dipenuhi oleh para konsumen, dan ketika bisa atau tidak bisa diberikan kepada para produsen.

Kedua, struktur harga adalah pendorong laju produksi. Hal itu karena kaum kapitalis berpandangan, bahwa motivasi utama seseorang melakukan usaha yang produktif atau pengorbanan apapun adalah imbalan materi untuk pengerahan usaha atau pengorbanan tersebut.

33 Isâ A bduh, al-I qtishâd Islâmî M akhal wa M inhaj, (Kairo: Dâr al-I'tisham, 1974), hlm. 4. 
Kaum kapitalis menjauhkan orang untuk melakukan pengerahan usaha apapun dengan motivasi imaterial ataupun spiritual. Sementara motivasi moral yang eksistensinya mereka akui juga mereka kembalikan kepada imbalan materi. Mereka berpandangan, bahwa semua usaha yang dicurahkan seseorang hanya untuk memenuhi kebutuhan serta keinginan materialnya. ${ }^{34}$

Pemenuhan ini kadangkala dilakukan dengan mengkonsumsi barang dan jasa yang diproduksinya secara langsung atau dengan jalan memperoleh imbalan finansial sehingga dia dapat memperoleh barang dan jasa yang dihasilkan oleh orang lain. Karena dalam memenuhi sebagian besar kebutuhannya, jika tidak dapat disebut semuanya, seseorang bersandar kepada pertukaran hasil usahanya dengan hasil usaha orang lain, maka pemenuhan kebutuhankebutuhan tersebut didasarkan pada cara memperoleh imbalan finansial dari hasil usahanya yang memungkinkannya untuk memperoleh barang dan jasa, dan bukan didasarkan pada perolehan barang yang dihasilkannya.

Oleh karena itu, imbalan finansial atau harga (price) adalah pendorong manusia untuk berproduksi. Dari sini, harga jugalah yang mendorong para produsen untuk mencurahkan seluruh usaha mereka. Jadi, hargalah yang menjadi pendorong untuk melakukan produksi dalam political economy kapitalis. 35

Ketiga struktur hargalah yang juga akan mewujudkan keseimbangan antara produksi dan konsumsi. Karakter struktur harga dalam pemikiran ekonomi kapitalis akan mewujudkan keseimbangan antara produksi dan konsumsi, karena struktur harga tersebut merupakan media penghubung antara produsen dan konsumen.

Produsen yang merealisasikan seluruh keinginan konsumen akan mendapat imbalan dengan memperoleh keuntungan, sementara produsen yang produknya tidak diterima oleh para konsumen pasti akan berujung dengan kerugian, dan metode yang bisa digunakan produsen untuk menghentikan berbagai keinginan konsumen itu hanyalah harga (price), maka dengan metode harga tersebut, para

34 Ibid., hlm. 44

35 al-Nabhani, al-N izhâm, hlm. 15. 
produsen tadi akan mengetahui keinginan para konsumen. Hal itu dilakukan dengan mengamati kesediaan para konsumen untuk membeli barang tertentu yang harganya di pasar melambung. Dengan demikian, produksi barang-barang tersebut akan bertambah untuk memenuhi keinginan pasar.

Jika para konsumen tersebut menolak untuk membeli barang tertentu, maka harganya di pasar akan turun, kemudian para produsen juga akan mengurangi produksi barang tersebut. Bahanbahan dasar tertentu juga akan ditingkatkan produksinya, karena harganya naik, demikian juga bahan-bahan dasar tersebut akan berkurang produksinya, dengan turunnya harga bahan tersebut.

Dengan demikian, hargalah yang dapat mewujudkan keseimbangan antara produksi dan konsumsi, sekaligus menjadi sarana penghubung antara produsen dan konsumen. Ini semuanya berlangsung secara otomatis. Dari sini, harga merupakan kaidah yang menjadi dasar ekonomi politik (political economy) dalam naungan akidah kapitalisme. Pada waktu yang sama, harga juga merupakan batu fondasi sistem ekonomi kapitalis. ${ }^{36}$

Keempat, peran struktur harga dalam supply and demand. Selama struktur harga memainkan peranan penting dalam produksi dan konsumsi, dilihat dari segi bahwa hargalah yang menentukan produsen untuk yang bisa memasuki area produksi dan siapa di antara mereka yang tetap jauh dari kelompok produsen tersebut, maka selama itu harga memainkan peranan yang sangat penting dalam strategi supply and demand di pasar.

Dalam pandangan kaum kapitalis, harga bisa menentukan mekanisme yang dengan ketentuannya itu mayoritas konsumen akan mampu menikmati pemenuhan kebutuhan mereka, dan siapa saja di antara mereka yang kebutuhannya tidak terpenuhi. Karena beban produksi barang juga merupakan faktor utama yang menentukan permintaan pasar atas barang tersebut, sementara masing-masing supply and demand tersebut ditentukan dengan harga. Karena itu, pembahasan supply and demand tersebut juga merupakan kajian ekonomi terpenting menurut kaum kapitalis.

36 lbid., hlm. 16-17. 
Yang dimaksud dengan supply (penawaran) adalah penawaran pasar, sedangkan yang dimaksud dengan demand (permintaan), juga permintaan pasar. Karena demand (permintaan) tersebut tidak dapat ditentukan tanpa menyebut harga, maka demikian halnya supply (penawaran), juga tidak dapat diperkirakan tanpa menyebutkan harganya. Akan tetapi, permintaan bisa berubah secara berlawanan dengan perubahan harga. Jika harga naik, permintaan menurun, sebaliknya jika harga turun, permintaan akan naik. Berbeda dengan penawaran. Penawaran berubah dengan berubahnya harga, dan searah dengan (arah perubahan)-nya, artinya penawaran tersebut bertambah dengan naiknya harga dan turunnya harga.

Dalam dua kondisi tersebut, harga memiliki pengaruh paling besar terhadap supply and demand; artinya harga tersebut mempunyai pengaruh terbesar dalam kebijakan produksi, konsumsi dan distribusi. ${ }^{37}$ Kesimpulan pandangan yang dianut para ekonom Barat mengenai teori harga (theory of price) adalah, bahwa harga merupakan pendorong laju produksi. Mereka menganggap, bahwa yang mendorong manusia untuk mencurahkan tenaga adalah imbalan atas usahanya secara materi.

Manusia hidup di alam ini banyak mencurahkan tenaga secara fisik untuk mendapatkan imbalan yang bersifat emosional (nonmateri), seperti kebanggaan, misalnya. A tau untuk mendapat imbalan yang bersifat spiritual, seperti mendapatkan rida Allâh, atau untuk memperoleh sifat moralitas, seperti menunaikan janji.

Sementara kebutuhan manusia kadang ada yang berbentuk materi, seperti keuntungan materi, kadang ada yang berbentuk spiritual, seperti pengagungan, atau berbentuk emosional seperti pujian. Pembahasan kaum kapitalis terhadap kebutuhan dengan hanya terbatas pada kebutuhan materi tentu saja tidak benar. Karena yang terlihat secara empiris, membuktikan bahwa kadang-kadang manusia mengorbankan hartanya untuk memenuhi kebutuhan spiritual, atau emosional melebihi pengeluaran yang dikorbankan untuk memenuhi kebutuhan materialnya.

37 Lihat Hasysy, Târikh, hlm. 168-173 
Karena itu, tidak benar sebagaimana yang dikatakan oleh kaum kapitalis bahwa harga merupakan satu-satunya pendorong laju produksi. Karena, bisa jadi harga, dan bisa jadi yang lain.

Betapa aneh yang dinyatakan oleh sistem kapitalis yang menjadikan harga sebagai satu-satunya pengatur distribusi kekayaan kepada anggota masyarakat. Kemudian kaum kapitalis tersebut mengatakan, bahwa harga merupakan ketentuan yang menyebabkan manusia menghentikan pengumpulan (barang dan jasa) berdasarkan limit yang sesuai dengan kekayaannya. Itulah yang menyebabkan konsumsi tersebut dibatasi oleh apa yang dibenarkan oleh kekayaan individu. Dengan demikian, naik dan turunnya harga, serta ketersediaan uang pada sebagian orang serta ketidaktersediaan uang pada sebagian yang lain merupakan pengatur distribusi kekayaan kepada para konsumen.

Bagian masing-masing individu atas kekayaan negara bukan ditentukan berdasarkan kadar kebutuhan pokoknya, tetapi ditentukan setara dengan nilai jasa yang diinvestasikan dalam menghasilkan barang dan jasa. Dengan kadar sebidang tanah, modal, usaha yang dicurahkan atau pengaturan proyek-proyek dan sebagainya.

Dengan kaidah kapitalis yang telah menjadikan harga sebagai pengatur distribusi ini, maka pemikiran ekonomi kapitalis telah menetapkan, bahwa yang layak hidup hanyalah orang yang mampu memberikan kontribusi dalam menghasilkan barang dan jasa. Sementara orang yang tidak mampu melakukan hal itu, baik karena dia diciptakan dalam keadaan lemah atau karena ada kelemahan yang terjadi akibat faktor ketuaan atau sakit, maka orang tersebut tidak layak hidup.

Oleh karena itu kaum kapitalis memandang, bahwa orang tersebut tidak layak mendapatkan kekayaan negara agar bisa memenuhi kebutuhan pokoknya.38 Adapun orang yang mampu berproduksi, dia berhak untuk menikmati, berkuasa dan memimpin, karena dia telah diciptakan sebagai orang yang kuat, baik fisik

38 Inilah pendapat sistem kapitalis yang bertentangan dengan teori para tokoh Gereja abad pertengahan. Lihat juga Henyeyan Lewis H, H istory of E conomic Thought, cet. IV, hlm. 99. 
maupun akalnya. Dia juga lebih mampu dibanding dengan orang lain untuk mengumpulkan (barang dan jasa) dengan cara apapun.

Dengan demikian, menjadikan struktur harga sebagai penentu distribusi benar-benar telah menjadikan monopoli kapitalistik di Barat merambah ke pasar-pasar internasional untuk mencari bahan mentah dan memasarkan produknya di pasaran internasional. 39

Jadi apa yang diderita oleh dunia akibat imperialisasi, dan wilayah cengkraman, serangan ekonomi, tidak lain kecuali merupakan akibat dari perusahaan-perusahaan monopoli dan akibat dijadikannya harga sebagai pengendali distribusi kekayaan kepada anggota masyarakat. A kibatnya, kekayaan dunia tersebut terkumpul dengan asas ini untuk diserahkan ke tangan-tangan monopoli kapitalis. Semua hal itu merupakan akibat dari buruknya kaidah yang dinyatakan oleh sistem ekonomi kapitalis. 40

\section{Penutup}

Sistem kapitalisme disamping mempunyai kekuatan ternyata mempunyai banyak kelemahan dan ketimpangan di dalam konsepnya sehingga sebuah pemikiran yang logis ketika konsep kapitalisme ini dimana konsep tersebut dianggap penyebab ketidak adilan dan ketimpangan dalam kehiduoan ekonomi. Konsekuensi logisnya adalah pencarian alternatif merupakan sebuah pikiran dan tindakan yang pantas diajukan. Konsep Islâm hadir sebagai alternatif untuk mengurangi ketidak adilan, ketimpangan dan gap di bidang kehidupa ekonomi menuju sebuah kondisi yang diharapkan lebih adil, lebih seimbang dan berorientasi terhadap kesejahteraan bagi semua. Wallâh a'la bi al-shawâb.

\section{D aftar Pustaka}

A bd Allâh, Muhammad Husayn. Mafâhim Islâmiyyah, Juz 1. Beirut: Dar al-Bayâriq, 1994.

39 al-Nabhani, N izhâm, hlm. 42

40 Paul Buran menyatakan bahwa sesungguhnya sistem kapitalis yang dulu merupakan penggerak dan menguasai perkembangan ekonomi telah berubah menjadi penghalang kemajuan manusia. Lihat Paul Buran, al-I qtishâdi al-Siyâsî wa alTahniyyah, terj. A hmad Balba' (Kairo: Dâr al-Qalam, 1967), hlm. 376. 
Kapitalismedan I Sâm

A bduh, Isâ. al-Iqtishâd Islâmî M akhal wa M inhaj. Kairo: Dâr al-I'tisham, 1974.

Brewer, Anthony. Kajian Kritis Das Kapital Karl Marx, terj. Joebaar Ajoeb. Jakarta: Teplok Press, 2000.

Budiman, Hikmat. Pembunuhan yang Selalu Gagal Modernisme dan Krisis Rasionaitas menurut Danniel Bell, Yogyakarta: Pustaka Pelajar, 1997

Buran, Paul. al-Iqtishâdi al-Siyâsî wa al-Tahniyyah, terj. Ahmad Balba' (Kairo: Dâr al-Qalam, 1967.

Chapra, Umer. Sistem M oneter Islam (Jakarta: Gema Insani Press, dan Tazkia Cendekia, 2000.

Ester, Jhon. Karl Marx, Marxisme: A nalisis Kritis, terj. Sudarmaji. Jakarta: Prestasi Pustaka Karua, 2000.

Grossman, Gregory. Sistem Ekonomi Islam. Jakarta: Bumi Aksara, 1995.

Halim, Fachrizal A. Beragama dalam Belenggu Kapitalisme. Magelang: Indonesia Tera, 2002.

Harwood, Jamal. ed. M embedah Krisis Keuangan Global, ter.MR Adhi. Bogor: Pustaka Thariqul Izzah,2009.

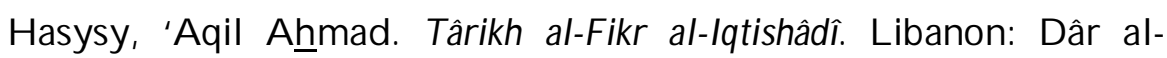
Nahdlah al- 'A rabiyah, 1974.

Hawari, Muhammad. Reldeologi Islam Membumikan Islam Sebagai Sistem, Bogor:al-Azhar, 2005.

Khalidi, Mahmud al. Kerusakan dan Bahaya Sistem Ekonomi Kapitalis. Jakarta: Wahyu Pres,2002.

Mâlikî, Abd al-Rahmân al-. Al-Siyâsat al-Iqtishâdiyah al-M usthla (AlQuds Hizb al-Tahrir, 1963.

Mannan, Abdul. Teori dan Praktek Ekonomi Islam, Yogyakarta: Dana Bhakti Prima Yasa, 1997

Marx, Karl. N aqd al-Iqtishâdi Siyâsî, terj. Rasyid al-Banawî. Beirut: Dâr al-N ahdlah al-'A rabiyyah, 1969. 
Mills, C. Wrigh. Kaum Marxis: Ideide Dasar dan Sejarah Perkembangannya, terj. Imam Muttaqien. Yogyakarta: Pustaka Pelajar, 2003.

Nabhani, Taqi al-Dîn al-. N izhâm al- Islâm, Cet. VII. tt.: Hizbut Tahrir, 2001.

Najjar, A hnmad al-. A I-M adkhal Ilâ Nazhariyyah al-lqtishâdiyyah alIslâmiyyah. Beirut: Dâr al-Fikr, 1974.

Pals, Daniel L. Seven Theories of Religion (London: Oxford University, Press, 1996.

Rohmah, Iffah. Kesengsaraan Dunia: Buah Sistem Ekonomi KapitalisLiberalis, Makalah Muktamar Majelis Taklim,Jatim Internasional Expo Surabaya,28 Desember 2008

Rosyidi, Suherman. Pengantar Teori Ekonomi Pendekatan Kepada Teori Ekonomi M ikro dan M akro. Jakarta: Raja Grafindo Persada, 2004.

Sahrasad, Herdi (ed). Islam, Sosial isme dan Kapitalisme, Jakarta: Madani Press, 2000

Siddiqi, Muhammad Nejatullah. M uslim Economic Thinking, A Survey of Contemporary Literature (Jeddah: International centre for Research in Islamic Economics King Abdul Aziz University; leicester UK: The Islamic Fondation, 1981.

Su'ûd, Mahmûd A bu al-. Khutut Raisiyyah fî al-Iqtishâdi Islâmî. Kuwait: Maktabah al Manâr al-Islâmiyah, 1968.

Zallum, Abdul Qadim. Serangan A merika untuk M enghancurkan Islam, terj. M. Al-Khaththath. Bogor: Pustaka Thariqul Izzah, 1996. 